\title{
Development of Ownership Structure and its Effect on Performance: Czech Firms from Mass Privatization
}

\author{
Evžen Kočenda
}

\begin{abstract}
This paper works with a broad data sample of Czech voucher-privatized firms during 1996-1999. It analyzes the development of ownership structure and consequently its effect on a firm's performance Ownership concentration had been quite high in 1996 and steadily increased. The single largest owner was found to be a decisive shareholder. Industrial companies have been the most stable shareholder and recorded the largest ownership gains. Ownership concentration alone does not explain a change in a firm's performance and no industry sector was found to have a specific effect on it. We found evidence that several types of owners have an effect on certain performance measures. However, there does not exist support that type of owner has an effect on a firm's performance in general.
\end{abstract}

\begin{abstract}
Abstrakt
Tento článek pracuje s širokým vzorkem dat českých kupónově privatizovaných firem v období let 1996-1999. Analyzujeme vývoj vlastnické struktury a následně její vliv na podnikovou výkonnost. Koncentrace vlastnictví byla v roce 1996 poměrně vysoká a postupně dále rostla. Jediný největší vlastník byl shledán rozhodujícím akcionářem: průmyslový podnik se jeví jako nejstabilnější akcionář-vlastník a v rozsahu vlastnictví zaznamenal také největší prrírůstky. Samotná koncentrace vlastnictví nevysvětluje změny v podnikové výkonnosti a žádné hospodářské odvětví na ni nemá specifický vliv. V př́padě několika typů vlastníků jsme nalezli důkazy o jejich vlivu na specifické ukazatele podnikové výkonnosti. V obecné rovině jsme však podporu pro vliv typu vlastníka na výkonnost nenalezli.
\end{abstract}

JEL: C23, D21, G32, L20.

Keywords: Ownership structure, firm's performance, voucher privatization, type of owner, panel data

I would like to thank Randall Filer and Lubomír Lízal for their comments and Juraj Valachy for research assistance. Partial funding from the ACE project P97-8201 is gratefully acknowledged. The usual disclaimer applies.

Correspondence to: Evžen Kočenda, Center for Economic Research and Graduate Education and Economics Institute (CERGE-EI), P.O.Box 882, Politických vězňů 7, 11121 Prague, Czech Republic, tel. (420-2) 24005149, fax (420-2) 24227143, e-mail: evzen.kocenda@cerge-ei.cz 


\section{Introduction and Motivation}

The Czech voucher privatization scheme is part of a transition process which can be considered a unique natural experiment rarely seen on such a scale in the real economy. Voucher privatized firms swiftly became legally private subjects of the emerging market economy. This paper analyzes the development of ownership structure and its effect on performance using an extensive sample of Czech voucher privatized firms during 1996-1999. ${ }^{1}$

First we investigate changes in ownership structure of voucher-privatized companies based on degree of ownership concentration and type of largest owner. Further, we analyze relationships between ownership and economic performance of firms. In particular we address the question whether a change in ownership concentration of a certain type of shareholder has an impact on a firm's performance.

The critical assumption behind privatization in many parts of the world is that private ownership together with its concentration improves corporate performance. The empirical evidence for this assumption comes from two kinds of studies. The first compares the pre- and post-privatization financial and operating performance (see D'Souza and Megginson, 1999, among others). They compare the pre- and postprivatization financial and operating performance of firms in 28 industrialized countries that were privatized through public share offerings during the period from 1990 to 1996 . They document significant increases in profitability, output, operating efficiency, and dividend payments, and significant decreases in leverage ratios of

\footnotetext{
${ }^{1}$ The privatization program in the Czech Republic was carried out under different schemes: restitution, small-scale privatization and large-scale (or mass) privatization. The first two started in 1990 and were most important during the early years of transition. Large privatization began in 1991 and was concluded in early 1995. These issues have been extensively described in the literature and therefore we do not elaborate on them in this paper. For classical approaches and analysis of pre-privatization and privatization issues see, among others, Blanchard, Dornbusch, Krugman, Layard, and Summers (1991), Aghion, Blanchard, and Burgess (1994), and Aghion, Blanchard, and Carlin (1994).
} 
firms after privatization. These findings strongly suggest that privatization yields significant performance improvements.

The second strand focuses on comparing the performance of state firms with either private (Boardman and Vining, 1989) or privatized (Pohl, Anderson, Claessens, and Djankov, 1997) firms operating under reasonably similar conditions. Additional evidence has been obtained recently from a number of studies of the post-communist transition economies which, because of the existence both state and privatized firms, have become a favorable testing ground for the general claim that privatization is effective (see for example Frydman, Gray, Hessel and Rapaczynski, 1997, or Dharwadkar and Brandes, 2000).

The overall impact of privatization- in spite of expectations - is not always positive. There are many empirical studies about the impact of different types of privatization on enterprise performance. Havrylyshyn and McGettingan (2000) review literature on this topic. In order to evaluate the impact of privatization Frydman, Gray, Hessel, and Rapaczynski (1999) compare the performance of privatized and state firms in the transition economies of Central Europe, while controlling for various forms of selection bias. They argue that privatization has different effects depending on the types of owners to whom it gives control. In particular, privatization to outsider owners has significant performance effects. Where privatization is effective, the effect on revenue performance is very pronounced, but there is no comparable effect on cost reduction. Overlooking the strong revenue effect of privatization to outsider owners leads to a substantial overstatement of potential employment losses resulting from post-privatization restructuring.

A further set of issues related to privatization stems from the post-privatization structure of ownership and its subsequent evolution. It is the usual wisdom that 
dispersion of ownership has a bad influence on a firm's performance. Shleifer and Vishny (1997) survey research on corporate governance, with special attention to the importance of legal protection of investors and of ownership concentration in corporate governance systems around the world. McConnell and Servaes (1990) examine the impact of ownership structure on company economic performance in the largest European companies. Controlling for industry, capital structure and nation effects they find a positive effect of ownership concentration on market-to-book value of equity and profitability. Furthermore they propose and support the hypothesis that the identity of large owners - family, bank, institutional investor, government, and other companies - has important implications for corporate strategy and performance. The effect of ownership concentration is also found to depend on owner identity. On the other hand, studies by Coase (1988) or Demsetz and Lehn (1985) argue that the relation between ownership concentration and corporate performance is spurious. Also Leech and Leahy (1999) found out that control-type effects have no clear effect a on firm's performance.

Smith, Cin, and Vodopivec (1997) examine the relation between employee or foreign ownership and firm performance. They find that a percentage point increase in foreign ownership is associated with about a 3.9 percent increase in value-added and for employee ownership with about a 1.4 percent increase. Claessens and Djankov (1999) find that the more concentrated the ownership, the higher the firm's profitability and labor productivity. Estrin and Rosevear (1999) explore whether specific ownership forms have led to different performances among firms in Ukraine. They refute the hypothesis that private ownership per se is associated with improved performance. As a performance proxy they use profit, sales, and employment. 
The remaining part of article is organized as follows: In the second part we investigate the evolution of ownership structure and in the third section we analyze the relation between concentration and performance. A brief conclusion follows.

\section{Development of Ownership Structures}

The years 1991-1995 were marked by the ongoing process of voucher privatization. The resulting ownership structure after both waves was more or less an outcome of the logistics of the voucher scheme's administration. In early 1995 the voucher privatization scheme was officially concluded and subsequent changes in ownership also reflected legal requirements to prevent excessive stakes being held by privatization funds. More economically meaningful patterns of ownership structure began to emerge in Czech companies in 1996. Since our goal is to examine the changes in ownership structure of firms involved in the voucher privatization, we focus our attention on these firms but supply some comparison with firms that did not fall under the scheme as well.

\subsection{Concentration of Ownership}

The data sample was compiled from the commercial database Aspekt Ltd. and the National Property Fund of the Czech Republic. It contains 645 firms for which reported ownership data overlapped over the four year period. The voucher privatized firms in the sample were involved in the first, second, or both waves of the voucher privatization. The sample thus contains yearly ownership data for nearly $40 \%$ of the 1664 firms that were privatized within the voucher scheme. ${ }^{2}$

\footnotetext{
${ }^{2}$ The first wave involved shares in 988 firms. The second one included shares in an additional 676 firms plus unsold shares in 185 firms carried over from the first wave.
} 
The voucher scheme did not fulfill its main mission to cut the ownership link between the State and firms since a large amount of residual state property was left after the voucher scheme ended along with significant potential control of the State over a substantial part of the economy. Indeed, during the years 1996-1999 the share stakes of the State in the (already) voucher privatized companies remained large and only recently and slowly has the amount of residual state property begun to diminish (see Kocenda, 1999). A complicated web of interlocking and non-transparent ownership structures emerged after the privatization was officially completed and thus the Czech Republic does not offer a clear data environment to work with. The climate may be illustrated by a situation in which a bank and an Investment Privatization Fund (IPF) owned by such a bank are among a firm's five largest owners. In such a situation these two owners would surely act together - for example at the general shareholders' meeting - and thus should be understood as a coalition. Such a coalition is naturally reinforced when the State has a major stake in a bank. There are also less obvious cases of interlocking ownership which, however, cannot be dealt with due to the limitations of the data as well as measurement obstacles (see Turnovec, 1999).

Figure 1 presents plots of densities of concentration indices $\mathrm{C} 1$ (single largest owner), and C5 (five largest owners) for 645 firms involved in voucher privatization. Each line represents a different year. All plots are the non-parametric densities, using the Epanechnikov kernel (Epanechnikov, 1969). Ownership concentration measured by $\mathrm{C} 1$ resembles a bi-modal distribution since it exhibits two prominent regions where concentration occurs.

It is the left region, that spans between 0 and $35 \%$, which shows quite a high percentage of firms that fall here in 1996; their proportion gradually decreases thereafter. In particular, the number of firms with $\mathrm{C} 1$ in the interval $\langle 0,35\rangle$ decreased 
from 317 firms in 1996 to 151 firms in 1999. The second region centers around the value $50 \%$. The number of firms around this second hump has slightly increased during the four years. In general, from Figure 1 we see that in 1996 the density of C1 looks more or less like a bi-modal distribution but, over the four year period, it has become in its appearance closer to a normal distribution in 1999. Overall, the mean value of $\mathrm{C} 1$ in our sample increased from $38.9 \%$ to $52 \%$, as documented in Table 1.

Figure 1 also shows that the density function of the C5 index has gradually shifted to the right, indicating a clear increase in ownership concentration of the five largest shareholders. Table 2 complements the above figure, as it shows how the mean value of the C5 index has increased from $57.4 \%$ in 1996 to $69.2 \%$ in 1999.

Both sets of findings are fully confirmed by the evolution of the Herfindahl index (table not included) that serves as an alternative measure of ownership concentration with respect to the $\mathrm{C} 1$ and $\mathrm{C} 5$ indices. The density of the index has become flatter and its mean value has increased from 0.22 in 1996 to 0.35 in 1999.

In our sample of 645 firms involved in voucher privatization, there were 433 firms privatized during the first wave, 91 during the second, and 121 firms privatized gradually during both waves. In order to distinguish any possible characteristics that might be specific to either the first or second wave of voucher privatization we computed similar sets of statistics, as well as densities for three sub-samples of firms. We found any specific characteristics to be insignificant and we do not report them. Based on this result we do not distinguish in our further analysis whether a certain firm was involved in the first, second, or both waves of voucher privatization. The decisive parameter is whether a firm was involved in voucher privatization or not.

Following our previous results we investigate whether there are any similarities in density functions of concentration indices and their evolution over time between 
voucher privatized firms and those that were not involved in the voucher scheme. We computed exactly the same characteristics for 105 such firms (figures and tables are not reported). The shape of the $\mathrm{C} 1$ density was found to be similar to the density of the Student distribution. Moreover, the density function of the C5 became each year flatter and flatter, and in 1999 index C5 was roughly uniformly distributed across the interval $(0,100)$. This is in sharp contrast with the skewed density of the $\mathrm{C} 5$ in the case of privatized firms.

Despite the fact that the samples of firms involved in voucher privatization and those not involved in it differ in size, we found that voucher privatized firms have a persistently higher mean of ownership concentration. Further, voucher privatized firms experienced more pronounced changes in ownership concentration and its evolution was less regular. Even further, voucher privatized firms experienced their largest change in ownership concentration within the part of the sample containing firms where the single largest investor held a stake of from 15 to $35 \%$.

\subsection{Changes in Type of Owner}

The preceding shifting perspective of the changes in ownership structure necessitates an analysis of changes in types of single largest owner of a firm. In our data set we distinguish six types of owners: industrial company, bank, investment fund, individual owner, portfolio company, and state. ${ }^{3}$

The previous description of ownership concentration movements is amended by the evolution of the mean ownership position of a particular type of single largest owner. Table 3 shows the mean and standard deviation of the $\mathrm{C} 1$ index. The computed mean

\footnotetext{
${ }^{3}$ There is a difference between an investment fund and a portfolio company. An investment fund buys shares of a certain company in order to exercise voting rights and to acquire profit from the company later. On the other hand, a portfolio company buys shares of a certain firm in order to sell these shares
} 
is an arithmetic average of all shares of owners belonging to a particular group of owners, and is calculated only for those firms in which this group appears as the single largest owner.

We can see an increase in the mean value of the $\mathrm{C} 1$ for all types of owners from 1996 to 1999, except for the bank category. The highest C1 mean value in 1996 within all categories occurs among industrial company single owners (46.7\%), and remained so in 1999. Investment funds have the lowest value of the mean of the $\mathrm{C} 1$ in 1996. However, in 1999 their mean value reaches values comparable with other types of owners. In general the highest average concentration increase between 1996 and 1999 was recorded in the case of investment funds (from 27.9 to 45.9 , a $64 \%$ increase) and portfolio companies (from 38.8 to 55.2, a $42 \%$ increase) as single largest owners. A decrease in mean holding can be observed in the case of banks (from 38.5 to 34.8 , a $10 \%$ decrease).

Since the mean share holding has only limited explanatory value, Figures 2 and 3 present the entire densities of ownership concentration by category of single largest owner over four consecutive years. We can see that over time the shapes of distribution distinctively change. An increase in share position is clearly visible in the humps moving from left to right. Recalling Figure 1 we can state that the two-hump density of ownership concentration reflects the pattern in stake rankings of industrial companies, investment funds, and individual owners. The disappearance of such a bimodal shape is the most prominent feature in the case of investment funds. Stakes of the state exhibit the largest tendency to increase over time, while the number of such firms decreases. This is fully in accord with the aim of the state to sell residual state property but to maintain power in companies of special interest.

for a higher price in order to realize a capital gain. A portfolio company does not attempt to exercise voting rights or extract corporate profits. 
Table 4 summarizes information about changes in type of single largest owner between the years 1996 and 1999 . We identify the following trends:

a) An industrial company is the most stable type of single largest owner, followed by an individual owner. In 78\% of firms whose single largest owner in 1996 was an industrial company, the same was true in 1999. An individual owner was in the same position in $58 \%$ of such firms.

b) The most unstable type of owner is a portfolio company. In 1999 only $5 \%$ of firms had such a single largest owner compared to 1996.

c) An industrial company is the category of owner that recorded by far the largest ownership gains. The evidence is presented by increases recorded in the first column of the table.

\section{Ownership and Performance}

\subsection{Methodology}

In the current literature the relationship of performance and ownership is investigated principally from the point of view of the effect of financial performance on the ownership structure, rather than from ownership structure to financial variables. Here we present an analysis of effect of ownership structure on economic performance.

We analyze the relationship between ownership structure and a firm's performance by employing three different panel-data models:

Model I $\quad g P e r_{i, t}=\alpha+\beta d C 1_{i, t}+\sum_{j=1}^{K} \gamma_{j} I_{j}+\sum_{m=1}^{3} \eta_{m} Y_{m}+u_{i}+\varepsilon_{i, t}$

Model II $\quad g P e r_{i, t}=\alpha+\beta d C 1_{i, t}+\sum_{n=1}^{L} \xi_{n} O S_{n, t}+\sum_{j=1}^{K} \gamma_{j} I_{j}+\sum_{m=1}^{3} \eta_{m} Y_{m}+u_{i}+\varepsilon_{i, t}$ 
Model III $\quad g P e r_{i, t}=\alpha+\beta d C 1_{i, t}+\sum_{n=1}^{L} \xi_{n} O_{n, t}+\sum_{j=1}^{K} \gamma_{j} I_{j}+\sum_{m=1}^{3} \eta_{m} Y_{m}+u_{i}+\varepsilon_{i, t}$

In all three models $\mathrm{gPer}_{i, t}$ is defined as the growth of a performance variable defined earlier, namely $g P e r_{i, t}=\left(\operatorname{Per}_{i, t}-\operatorname{Per}_{i, t-1}\right) / \operatorname{Per}_{i, t-1} . D C 1_{i, t}$ is the difference of ownership concentration indices between two consecutive years, namely $d C 1_{i, t}=C 1_{i, t}-C 1_{i, t-1}$.

$O S_{n, t}$ is a share of ownership of each category of owners in total ownership of a given firm and year, namely industrial company, bank, investment fund, individual owner, and portfolio company $(L=5)$. State as a common numeraire is represented by a constant term. The coefficients for other ownership categories thus represent deviations from the effect of State. $O_{n, t}$ is a dummy variable that indicates the type of single largest owner in a particular year. These categories are the same as those for $O S_{n, t}$ variables $(L=5) . O S_{n, t}$ variables are an alternative specification of $O_{n, t}$ variables. The difference between $O_{n, t}$ and $O S_{n, t}$ is that $O_{n, t}$ captures specifically the type of single largest owner, whereas the $O S_{n, t}$ variable captures the cumulative shares of all other owners in the firm of the same type. Such an approach allows us to investigate a broader picture of the relationship of ownership concentration and its structure to a firm's performance than is usual in the current literature.

Sector dummies, $I_{j}$, are used to capture sector-specific shocks. The Prague Stock Exchange classification contains 19 different types of industry sectors. We do not incorporate two of them, finance and banking, and investment funds, due to data insufficiency. Finally, $Y_{m}$ are year dummies to correct for changes in institutional environment as well as economy-wide shocks in a given year; $u_{i}$ represents the random effect.

\subsection{Measures of Performance and Data}


For further analysis we define a broad set of financial indicators in order to capture different aspects of a firm's performance: profitability, strength and size of the firm, its financial position, and its scope of business activity. The set of variables we use is divided based on the following criteria:

1. Profitability of a company: as measures of profitability we employ gross operating profit over sales revenue, per-cent growth in operating profit, and value-added over staff costs (wages).

2. Strength and size of a firm: we use change in total assets, change in fixed assets, and cash-flow over equity.

3. Financial position: as a measure we use a change in long-term and short-term bank loans.

4. Scope of business activity: we measure this performance by employing change in sales of own production.

Essential characteristics of the above financial variables in 1996 are shown in Table

5. The sample clearly represents a very diverse group of firms with both poor and good economic performance.

Overall we analyze nine different performance variables in contrast to two or three usually examined in the literature. The data sample originates from the same sources as in the previous section. We use the previously described ownership data together with financial data of Czech firms listed on the Prague Stock Exchange (PSE) for years 1996-1999. All financial variables were defined using international accounting standards. Due to serious limits of data availability we do not require that performance data of each particular firm be available for all four consecutive years. Instead we relax data availability to a minimum of three consecutive years in order to enlarge our sample size. Consequently, the sample consists of 722 firms that posted 
data for three ( $65 \%$ of firms) or four (35\% of firms) consecutive years within the interval 1996-1999 and covers more than $43 \%$ of voucher privatized firms. ${ }^{4}$

Despite the fact that the data sample covers a considerable portion of voucher privatized companies the data to pose limits to work within. Having firms' ownership and performance data does not mean that we know what information is available to an investor when his/her acquisition decision is made. Changes in ownership structure may be a function of an investor's prior knowledge of potential future performance of a firm rather than being exogenously determined.

The above requires that within the econometric part of our analysis we have to deal with problems of endogeneity of ownership structure. Two basic strategies can be used. The instrumental variable technique requires finding valid instruments. These instruments could be, for example, lagged values of the left-hand side variables. In our case it would be lagged concentration index. Then, regressing performance variable on concentration index using lagged values of index as an instrument would produce almost the same specification - changes in concentration index - as a lefthand side variable. The fact that the time dimension of our panel is disqualifies using the instrumental variable technique.

Instead of the above technique we use the first logarithmic differences of ownership concentration index to eliminate the endogeneity problem. In regression we also use growth rates of financial variables rather than their nominal values. Since the growth rates of financial variables are not correlated over time, such an approach also solves the problem of their rather high autocorrelation levels. The interpretation of coefficients in the case of growth variables is easy and straightforward.

\footnotetext{
${ }^{4}$ For two performance indicators (Cash Flow/Equity and Short-term Bank Loans) the scarcity of data reduced sample sizes.
} 
Due to the nature of the data in hand we are unable to entirely disentangle two issues: whether ownership affects performance or whether we can just better predict performance. Theory suggests approaching analysis of firms' performance with a direct control measure. The best proxy available is an ownership ratio but it is still an imperfect control measure. The following empirical results should be understood as the output of a serious attempt to research an important topic within transition literature, albeit conducted with the limited resources at hand.

\subsection{Empirical Results}

Results of all estimations are presented in Tables 6-14. In all regressions the $F$-test rejects the hypothesis that a common constant term across firms is appropriate. Moreover, the Hausman-specification test (Hausman, 1978) in all cases indicates that the random effect model is more appropriate than the specific effect model. Regarding sets of dummies, we chose state ownership and year 1996 as a common numeraire. Based on the insignificance of the respective dummy variables no industry sector was found to have a specific effect with respect to a firm's performance.

First, we estimated Model I. Based on our results we conclude that ownership concentration does not explain a change in a firm's performance. Since the coefficients of the variable for a change in index of single largest ownership concentration have different signs and magnitudes (albeit very small), it is tempting to discuss their effect on performance. However, we are left instead with their statistical insignificance.

Demsetz and Lehn (1985) argue that one should use the logistic transformation of the $\mathrm{C} 1$ or $\mathrm{C} 5$ index instead of its usual values. It is done to convert the bounded independent variable $\mathrm{C} 1$ into an unbounded one, defined as a logistic transformation 
$\ln [\mathrm{C} 1 /(100-\mathrm{C} 1)]$. We checked whether our results were sensitive to this transformation of ownership concentration and performed an analysis with a newly defined concentration variable as well. We report that all coefficients of the transformed ownership concentration variable were insignificant, the same as with our findings. Therefore, we consider our results to be robust with respect to alternative definition of the ownership concentration.

Claessens and Djankov (1999) performed a similar type of regression on data from Czech firms. They used only two measures of performance: profitability and labor productivity. Their definition of profitability is very similar to ours; therefore their results can be cautiously compared with ours. However, the difference is that they used data for years 1993-1996. In their regression, where they take into account endogeneity factors and autocorrelation of performance variables, they found ownership concentration (and its square) insignificant for a firm's profitability. Despite that we use a different time span, as well as a different data set, we conclude that our results are in line with theirs. Regarding labor productivity they find ownership concentration significant. Since we do not have data on employment, we could not construct any variable which would capture changes in employees' productivity and make any comparison with their findings on that basis.

We additionally analyze whether certain types of owners have a specific effect on firms' performance. Models II and III were estimated for this purpose. We regress the performance variables on ownership concentration and type of owner along with yearly and industry dummies. In the literature (Claessens and Djankov, 1999) it is usual to construct the share of ownership of each category in total ownership of a given firm. Since we are using the $\mathrm{Cl}$ index-share of single largest owner, we construct a set of dummy variables indicating the type of owner of this largest share. 
For comparision we report results for a cumulative share of a certain type in the firm as well.

Based on estimation of type II and III models we found the coefficient of change in ownership concentration to be insignificant in all regressions. This fact is in line with our results from Model I, and thus we conclude that we did not find any evidence for ownership concentration having an influence on firms' performance.

As for the effect of a particular type of owner the results do not provide evidence that in general the type of owner has an effect on a firm's performance. The overwhelming majority of respective coefficients were found to be statistically insignificant. We did not find any evidence in either Model II or III that the type of owner or its cumulative share would have an effect on firms' performance measured by defined indicators. This is the case for GOP/Sales, operating profit growth, value added/staff costs, growth of short-term bank loans, and growth of sales. Tables 6-8 and 13-14 present the evidence.

However, there exists clear and convincing evidence about the effect of a certain type of owner or its cumulative share on specific performance measures. Investment funds, either as single holders or cumulatively, tend to negatively affect growth of both total and fixed assets. Individual owners as single largest holders tend to negatively affect growth of total assets, while individual owners and industrial companies as cumulative shareholders show a negative impact on growth of fixed assets (Tables 10-11). The presence of the state (represented by a constant term) positively affects the cash flow/equity ratio, while portfolio company as a cumulative shareholder has a negative impact (Table 9). Industrial companies, either as single holders or cumulatively, tend to decrease the growth of long-term bank loans. The 
same is true for investment funds as single largest owners and banks as cumulative owners (Table 12).

\section{Conclusions}

The years 1991-1995 were marked by an ongoing process of voucher privatization. The resulting ownership structure after both its waves was more or less an outcome of the logistics of the voucher scheme's administration. In 1995 changes in ownership also reflected legal requirements to prevent excessive stakes being held by privatization funds. More economically meaningful patterns of ownership structure began to emerge in Czech companies in 1996.

The changes in ownership structure from 1996 to 1999 in voucher privatized firms was analyzed with respect to different concentration levels. The single largest owner was found to be a decisive shareholder.

The changes in ownership structure were then analyzed based on six types of owners: industrial company, bank, investment fund, individual owner, portfolio company, and state. In general the highest average concentration increase between 1996 and 1999 was recorded in the case of investment funds (from 27.9 to 45.9 , a $64 \%$ increase) and portfolio companies (from 38.8 to 55.2 , a $42 \%$ increase) as single largest owners. A decrease in mean holding can be observed in the case of banks (from 38.5 to 34.8 , a $10 \%$ decrease).

Detailed information about changes in type of single largest owner between the years 1996 and 1999 can be condensed in the following observations. Industrial companies are the most stable type of single largest owner, followed by individual owners. The most unstable type of owner is a portfolio company. In 1999 only 5\% of 
firms had such a single largest owner as in 1996. An industrial company is the category of owner that recorded by far the largest ownership gains over time.

Further we performed an econometric analysis of the effect of ownership structure on firms' economic performance. We defined a broad set of financial variables in order to capture different aspects of a firm's performance. A set of variables was selected to capture profitability of a company, strength and size of a firm, its financial position, and its scope of business activity. Moreover, in order to seize the effect of owner type on a firm's performance, we incorporated in our models two types of dummy variables for five different categories of owners, and a share of ownership per each category in total ownership of a given firm. Based on pre-testing procedures we adopted a random effect model.

Based on our results we conclude that ownership concentration does not explain a change in a firm's performance. Further, no industry sector was found to have a specific effect with respect to a firm's performance. Using a random effect model we did not find any overwhelming evidence that type of owner has an effect on a firm's performance. However, there exists clear and convincing evidence about the effect of a certain type of owner or its cumulative share on specific performance measures. 


\section{References:}

Boardman, Anthony E. and Aidan R. Vining. 1989. Ownership and Performance in Competitive Environments - A Comparison of the Performance of Private, Mixed, And State-Owned Enterprises. Journal of Law \& Economics 32 (1): 1-33, April 1989.

Claessens, Stijn, and Simeon Djankov. 1999. Ownership Concentration and Corporate Performance in the Czech Republic. Journal of Comparative Economics 27: 498513.

Coase, Ronald. 1988. Theory of the Firm? In Ronald Coase, Ed., The Firm, the Market, and the Law. Chicago/London: University of Chicago Press, 1988.

Demsetz, Heinz and Karl Lehn. 1985. The Structure of Corporate-Ownership - Causes and Consequences. Journal of Political Economy 93: (6) 1155-1177.

Dharwadkar R, Brandes George G. 2000. Privatization in emerging economies: An agency theory perspective. Academy of Management Review 25 (3): 650-669, July 2000.

D'Souza J., Megginson W. L. 1999. The financial and operating performance of privatized firms during the 1990s. Journal of Finance 54 (4): 1397-1438, August 1999.

Epanechnikov, Vassiliy A. 1969. Nonparametric estimation of a multidimensional probability density. Theoretical Probability Applications 14:153-158.

Estrin, Saul and Adam Rosevear. 1999. Enterprise performance and corporate governance in Ukraine. Journal of Comparative Economics 27: (3) 442-458, September 1999.

Frydman, Roman, Cheryl W. Gray, Marek Hessel, and Andrej Rapaczynski. 1999. When Does Privatization Work? The Impact of Private Ownership on Corporate Performance in the Transition Economies, Quarterly Journal of Economics 114(4): 1153-91, November 1999.

Frydman, Roman, Cheryl W. Gray, Marek Hessel and Andrej Rapaczynski. 1997. Private Ownership and Corporate Performance - Some Lessons from Transition Economies. World Bank Policy Research Working Paper No. 1830 (Washington: The World Bank).

Gupta, Nandini, John C. Ham, Jan Svejnar. 2000. Priorities and Sequencing in Privatization: Theory and Evidence from the Czech Republic. William Davidson Institute Working Paper No. 323.

Hausman, Jerry A. 1978. Specification Tests in Econometrics. Econometrica 46, 6:1251-1271, November 1978. 
Havrylyshyn, Oleg and McGettigan. 2000. Privatization in transition countries. PostSoviet Affairs 16: (3) 257-286, July-September 2000.

Kočenda, Evžen. 1999. Residual State Property in the Czech Republic. Eastern European Economics 37 (5): 6-35.

Leech, Dennis and John Leahy. 1999. Ownership structure, Control Type classification and the performance of large British companies. Economic Journal 101(409): 1418-1437, November 1991.

McConnell, John J. and Henri Servaes. 1990. Additional Evidence On Equity Ownership and Corporate Value. Journal of Financial Economics 27: (2) 595-612, October 1990.

Pohl, Gerhard, Anderson Robert E., Claessens Stijn and Djankov Simeon. 1997. Privatization and Restructuring in Central and Eastern Europe - Evidence and Policy Options, World Bank Technical Paper No.368 (Washington: the World Bank).

Shleifer, Andrei and Robert W. Vishny. 1997. A survey of corporate governance. Journal of Finance 52: (2) 737-783, June 1997.

Smith, Stephen C., Beom Cheol Cin, and Milan Vodopivec. 1997. Privatization Incidence, Ownership Forms, and Firm Performance: Evidence from Slovenia. Journal of Comparative Economics 25(2): 158-79, October 1997.

Turnovec, František. 1999. Privatization, ownership structure and transparency: how to measure the true involvement of the state. European Journal of Political Economy 15: 605-618. 
Table 1

Ownership Concentration Measured by C1 Index: Voucher Privatized Firms

\begin{tabular}{cccc}
\hline \hline $\begin{array}{c}\text { Concentration } \\
\text { Index (Year) }\end{array}$ & Num.of Obs. & Mean & Stand. Deviation \\
\hline \hline C1 (1996) & 645 & 38.91 & 19.28 \\
C1 (1997) & 645 & 42.80 & 20.38 \\
C1 (1998) & 645 & 48.62 & 21.51 \\
C1 (1999) & 645 & 51.82 & 21.79
\end{tabular}

Table 2

Ownership Concentration Measured by C5 Index: Voucher Privatized Firms

\begin{tabular}{cccc}
\hline \hline $\begin{array}{c}\text { Concentration } \\
\text { Index (Year) }\end{array}$ & Num.of Obs. & Mean & Stand. Deviation \\
\hline \hline C5 (1996) & 645 & 57.40 & 19.90 \\
C5 (1997) & 645 & 61.29 & 19.95 \\
C5 (1998) & 645 & 67.04 & 19.44 \\
C5 (1999) & 645 & 69.17 & 19.10
\end{tabular}

Table 3

Ownership position of the particular types of single largest owner

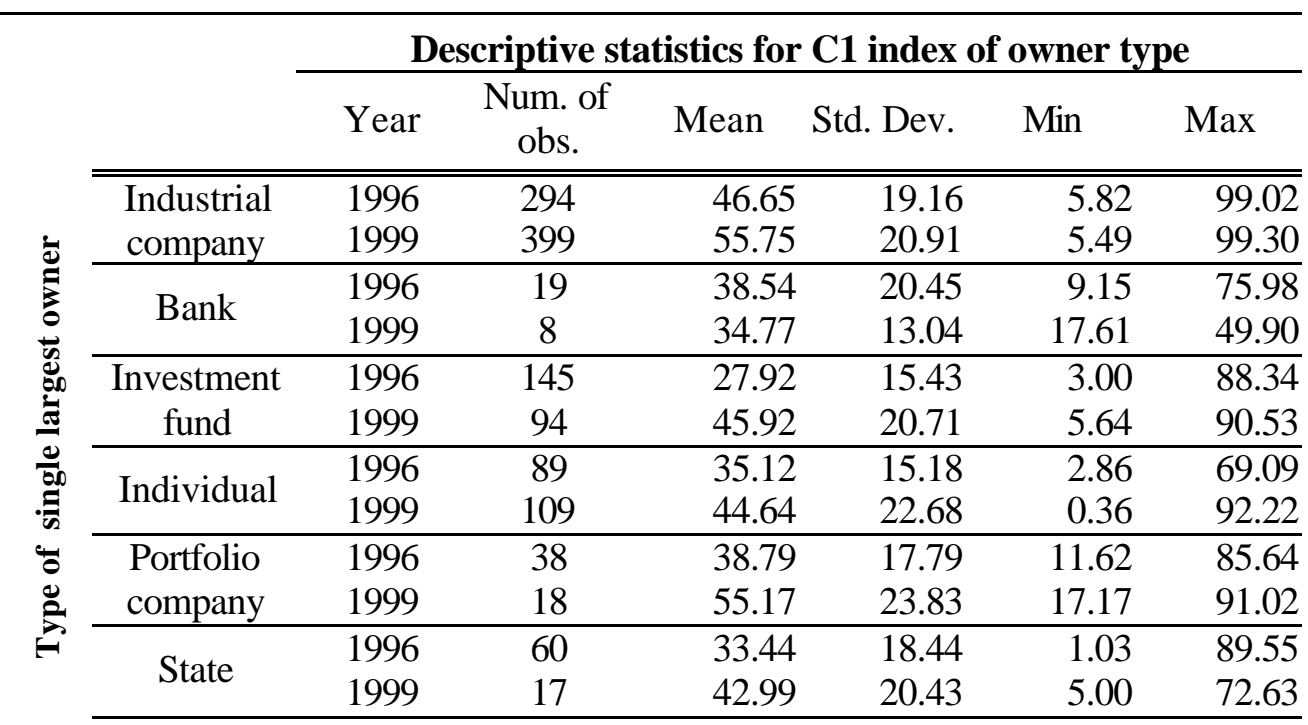


Table 4

Changes in Ownership Concentration by Type of Single Largest Owner: 1996-1999

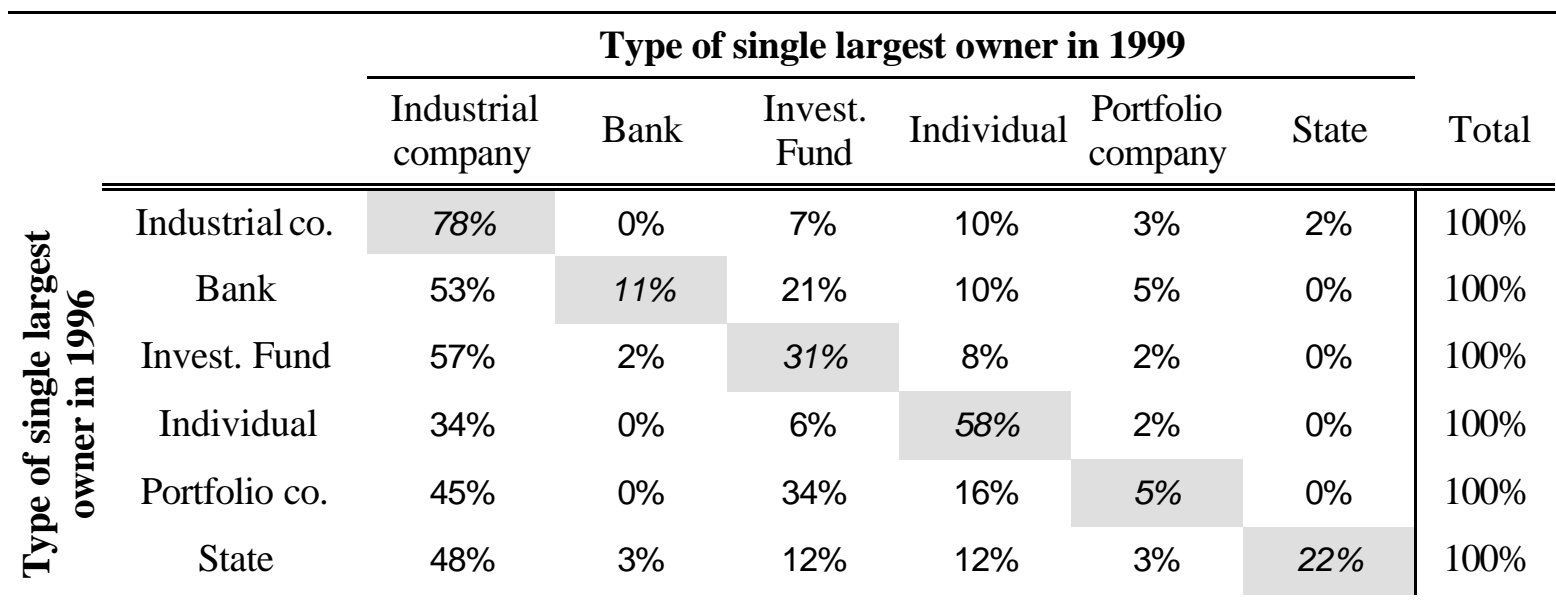

Table 5

Basic characteristics of growth rates of financial variables: 1996-1999

\begin{tabular}{lcrrrr}
\hline \hline & $\begin{array}{c}\text { No. of } \\
\text { Firms }\end{array}$ & \multicolumn{2}{c}{ Mean } & \multirow{2}{*}{ Std. dev. } & \multicolumn{2}{c}{ Min } & \multirow{2}{*}{ Max } \\
\hline Gross operating profit / Sales & 722 & -0.059 & 1.547 & -7.153 & 4.847 \\
Operating Profit & 722 & 0.054 & 1.435 & -5.513 & 4.560 \\
Value Added / Staff Costs & 722 & 0.047 & 0.503 & -2.847 & 5.095 \\
Total Assets & 722 & -0.006 & 0.161 & -0.658 & 0.847 \\
Fixed Assets & 722 & 0.001 & 0.198 & -0.749 & 1.434 \\
Cash Flow / Equity & 436 & 0.047 & 0.263 & -0.297 & 0.733 \\
Long-term Bank Loans & 722 & -0.245 & 0.521 & -1.000 & 1.965 \\
Short-term Bank Loans & 577 & -0.108 & 0.546 & -1.278 & 1.758 \\
Sales of Own Production & 722 & 0.040 & 0.351 & -0.951 & 3.407
\end{tabular}


TABLE 6

Gross operating profit / Sales

\begin{tabular}{c} 
Change in C1 \\
\cline { 2 - 4 }
\end{tabular}

TABLE 7

Operating Profit

Model I Model II Model III

\begin{tabular}{llll}
\hline \hline Change in C1 & 0.001 & 0.001 & 0.001 \\
& $(0.003)$ & $(0.003)$ & $(0.003)$
\end{tabular}

Constant $\quad-0.278 \quad-0.282 \quad-0.342$

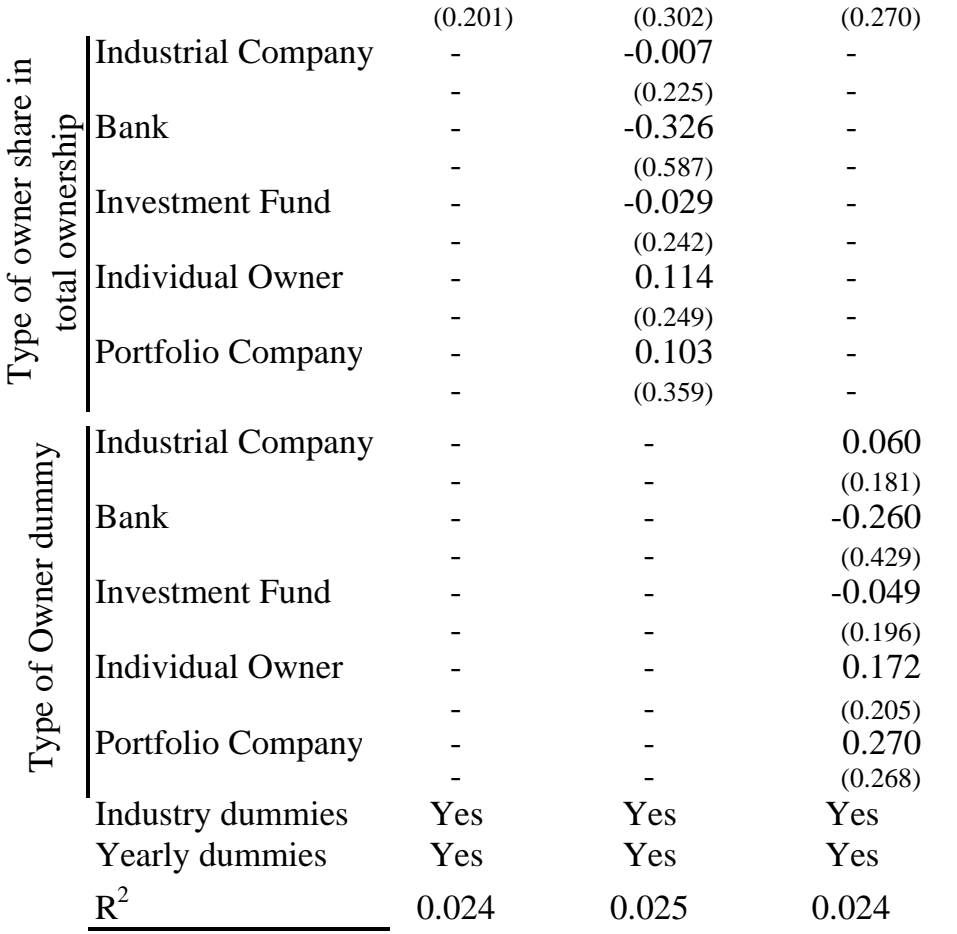

Note: Standard errors are in parentheses.

Yes means that specific dummies are included in regressio 
TABLE 8

Value Added / Staff Costs

\begin{tabular}{|c|c|c|c|c|}
\hline & & Model I & Model II & Model III \\
\hline & Change in $\mathrm{C} 1$ & $5.90 \mathrm{E}-04$ & 5.59E-04 & $4.51 \mathrm{E}-04$ \\
\hline & & (9.4E-04) & (9.6E-04) & $(9.5 \mathrm{E}-04)$ \\
\hline & Constant & 0.053 & 0.038 & -0.003 \\
\hline & & $(0.076)$ & $(0.114)$ & $(0.101)$ \\
\hline & |Industrial Company & - & 0.013 & - \\
\hline & & - & $(0.084)$ & - \\
\hline छ. ? & Bank & - & -0.057 & - \\
\hline के क्ष & & - & $(0.211)$ & - \\
\hline $\bar{\Xi} \bar{\Xi}$ & Investment Fund & - & 0.002 & - \\
\hline है & & - & $(0.091)$ & - \\
\hline$+\frac{\pi}{0}$ & Individual Owner & - & 0.025 & - \\
\hline$\approx$ 。ㅇ & & - & $(0.093)$ & - \\
\hline & Portfolio Company & - & 0.093 & - \\
\hline & & - & $(0.132)$ & - \\
\hline$\lambda$ & |Industrial Company & - & - & 0.057 \\
\hline$\Xi$ & & - & - & $(0.067)$ \\
\hline$\Xi$ & Bank & - & - & 0.005 \\
\hline 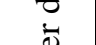 & & - & - & $(0.153)$ \\
\hline$\stackrel{\mathscr{s}}{\xi}$ & Investment Fund & - & - & 0.062 \\
\hline bُ & & - & - & $(0.073)$ \\
\hline 4 & Individual Owner & - & - & 0.047 \\
\hline 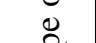 & & - & - & $(0.076)$ \\
\hline$\sum_{1}^{2}$ & Portfolio Company & - & - & 0.131 \\
\hline & & - & - & $(0.098)$ \\
\hline & Industry dummies & Yes & Yes & Yes \\
\hline & Yearly dummies & Yes & Yes & Yes \\
\hline & $\mathrm{R}^{2}$ & 0.024 & 0.025 & 0.024 \\
\hline
\end{tabular}

TABLE 9

Cash Flow/Equity

\begin{tabular}{|c|c|c|c|c|}
\hline & & Model I & Model II & Model III \\
\hline & Change in $\mathrm{C} 1$ & $-8.91 \mathrm{E}-05$ & $1.07 \mathrm{E}-04$ & $3.87 \mathrm{E}-05$ \\
\hline & & (7.4E-04) & (7.5E-04) & $(7.5 \mathrm{E}-04)$ \\
\hline & Constant & 0.035 & 0.114 & $0.088^{\mathrm{C}}$ \\
\hline & & $(0.058)$ & $(0.081)$ & $(0.074)$ \\
\hline & |Industrial Company & - & -0.083 & - \\
\hline & & - & $(0.056)$ & - \\
\hline 苂.? & Bank & - & -0.004 & - \\
\hline जै क्ञ & & - & $(0.160)$ & - \\
\hline 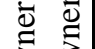 & Investment Fund & - & -0.078 & - \\
\hline 30 & & - & $(0.061)$ & - \\
\hline $4 \pi$ & Individual Owner & - & -0.042 & - \\
\hline$\approx 0$ & & - & $(0.064)$ & - \\
\hline$\overbrace{}^{0}$ & Portfolio Company & - & -0.130 & - \\
\hline & & - & $(0.086)$ & - \\
\hline & |Industrial Company & - & - & -0.053 \\
\hline$\widehat{\Xi}$ & & - & - & $(0.045)$ \\
\hline$\Xi$ & Bank & - & - & -0.111 \\
\hline $\bar{E}$ & & - & - & $(0.118)$ \\
\hline $\bar{\Xi}$ & Investment Fund & - & - & -0.063 \\
\hline 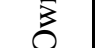 & & - & - & $(0.050)$ \\
\hline 4 & Individual Owner & - & - & -0.033 \\
\hline 0 & & - & - & $(0.053)$ \\
\hline$\sum_{1}^{2}$ & Portfolio Company & - & - & $-0.107^{C}$ \\
\hline & & - & - & $(0.064)$ \\
\hline & Industry dummies & Yes & Yes & Yes \\
\hline & Yearly dummies & Yes & Yes & Yes \\
\hline & $\mathrm{R}^{2}$ & 0.025 & 0.031 & 0.025 \\
\hline
\end{tabular}


TABLE 10

Total Assets

\begin{tabular}{|c|c|c|c|c|}
\hline & & Model I & Model II & Model III \\
\hline & Change in $\mathrm{C} 1$ & 4.36E-04 & $3.60 \mathrm{E}-04$ & 4.20E-04 \\
\hline & & (2.9E-04) & $(2.9 \mathrm{E}-04)$ & $(2.9 \mathrm{E}-04)$ \\
\hline & Constant & -0.026 & 0.020 & 0.001 \\
\hline & & $(0.024)$ & $(0.035)$ & $(0.032)$ \\
\hline & |Industrial Company & - & -0.034 & - \\
\hline & & - & $(0.026)$ & - \\
\hline 를. 욬 & Bank & - & -0.075 & - \\
\hline 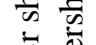 & & - & $(0.064)$ & - \\
\hline$\stackrel{\Phi}{=}$ & Investment Fund & - & $-0.075 \mathrm{~A}$ & - \\
\hline है & & - & $(0.028)$ & - \\
\hline $4 \pi$ & Individual Owner & - & $-0.053 \mathrm{C}$ & - \\
\hline 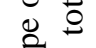 & & - & $(0.029)$ & - \\
\hline 논 & Portfolio Company & - & -0.066 & - \\
\hline & & - & $(0.040)$ & - \\
\hline$\gtrsim$ & |Industrial Company & - & - & -0.022 \\
\hline$\Xi$ & & - & - & $(0.021)$ \\
\hline$\Xi$ & Bank & - & - & -0.045 \\
\hline & & - & - & $(0.047)$ \\
\hline$\stackrel{\bar{D}}{\xi}$ & Investment Fund & - & - & $-0.050^{\mathrm{B}}$ \\
\hline ơ & & - & - & $(0.023)$ \\
\hline 4 & Individual Owner & - & - & -0.026 \\
\hline 0 & & - & - & $(0.024)$ \\
\hline i & Portfolio Company & - & - & -0.029 \\
\hline & & - & - & $(0.030)$ \\
\hline & Industry dummies & Yes & Yes & Yes \\
\hline & Yearly dummies & Yes & Yes & Yes \\
\hline & $\mathrm{R}^{2}$ & 0.062 & 0.072 & 0.062 \\
\hline
\end{tabular}

TABLE 11

Fixed Assets

\begin{tabular}{|c|c|c|c|c|}
\hline & & Model I & Model II & Model III \\
\hline & Change in $\mathrm{C} 1$ & $-2.27 \mathrm{E}-04$ & $-2.73 \mathrm{E}-04$ & $-2.26 \mathrm{E}-04$ \\
\hline & & (3.6E-04) & (3.7E-04) & (3.6E-04) \\
\hline & Constant & -0.024 & 0.034 & 0.033 \\
\hline & & $(0.030)$ & $(0.044)$ & $(0.040)$ \\
\hline & |Industrial Company & - & -0.052 & - \\
\hline & & - & $(0.033)$ & - \\
\hline छี & Bank & - & -0.041 & - \\
\hline की की & & - & $(0.081)$ & - \\
\hline$\stackrel{\bar{\Phi}}{\Xi}$ & Investment Fund & - & $-0.094 \mathbf{A}$ & - \\
\hline $3 \frac{5}{0}$ & & - & $(0.035)$ & - \\
\hline $4 \frac{\pi}{0}$ & Individual Owner & - & -0.059 & - \\
\hline$\ddot{\circ}$ & & - & $(0.037)$ & - \\
\hline & Portfolio Company & - & -0.017 & - \\
\hline & & - & $(0.051)$ & - \\
\hline & |Industrial Company & - & - & -0.052 в \\
\hline$\widehat{\Xi}$ & & - & - & $(0.026)$ \\
\hline$\Xi$ & Bank & - & - & -0.045 \\
\hline$=$ & & - & - & $(0.059)$ \\
\hline $\bar{\Xi}$ & Investment Fund & - & - & $-0.091 \mathrm{~A}$ \\
\hline है & & - & - & $(0.028)$ \\
\hline 4 & Individual Owner & - & - & $-0.055 \mathrm{c}$ \\
\hline 8 & & - & - & $(0.030)$ \\
\hline$\stackrel{2}{i}$ & Portfolio Company & - & - & -0.013 \\
\hline & & - & - & $(0.038)$ \\
\hline & Industry dummies & Yes & Yes & Yes \\
\hline & Yearlv dummies & Yes & Yes & Yes \\
\hline & $\mathrm{R}^{2}$ & 0.028 & 0.034 & 0.028 \\
\hline
\end{tabular}


TABLE 12

Long-term Bank Loans

\begin{tabular}{|c|c|c|c|c|}
\hline & & Model I & Model II & Model III \\
\hline & Change in $\mathrm{C} 1$ & $-9.22 \mathrm{E}-04$ & $-6.28 \mathrm{E}-04$ & $-6.05 \mathrm{E}-04$ \\
\hline \multirow{12}{*}{ 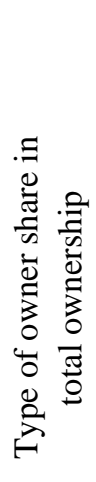 } & Constant & $\begin{array}{r}(9.3 \mathrm{E}-04) \\
-0455\end{array}$ & $\begin{array}{r}(9.0 \mathrm{E}-04) \\
-0.309\end{array}$ & $\begin{array}{r}(9.4 \mathrm{E}-04) \\
-0.359\end{array}$ \\
\hline & - & $(0.079)$ & $(0.118)$ & $(0.105)$ \\
\hline & |Industrial Company & - & $-0.169 \mathrm{C}$ & - \\
\hline & & - & $(0.087)$ & - \\
\hline & Bank & - & -0.165 & - \\
\hline & & - & $(0.212)$ & - \\
\hline & Investment Fund & - & $-0.155 \mathrm{C}$ & - \\
\hline & & - & $(0.093)$ & - \\
\hline & Individual Owner & - & -0.067 & - \\
\hline & & - & $(0.096)$ & - \\
\hline & Portfolio Company & - & -0.081 & - \\
\hline & & - & $(0.134)$ & - \\
\hline & |Industrial Company & - & - & -0.116 \\
\hline$\Xi$ & & - & - & $(0.069)$ \\
\hline$\Xi$ & Bank & - & - & -0.255 \\
\hline 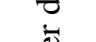 & & - & - & $(0.154)$ \\
\hline$\stackrel{D}{\equiv}$ & Investment Fund & - & - & -0.072 \\
\hline $3^{3}$ & & - & - & $(0.075)$ \\
\hline 4 & Individual Owner & - & - & -0.012 \\
\hline & & - & - & $(0.078)$ \\
\hline 空 & Portfolio Company & - & - & -0.103 \\
\hline & & - & - & $(0.099)$ \\
\hline & Industry dummies & Yes & Yes & Yes \\
\hline & Yearly dummies & Yes & Yes & Yes \\
\hline & $\mathrm{R}^{2}$ & 0.032 & 0.037 & 0.032 \\
\hline
\end{tabular}

TABLE 13

Short-term Bank Loans

\begin{tabular}{|c|c|c|c|c|}
\hline & & Model I & Model II & Model III \\
\hline & Change in $\mathrm{C} 1$ & $8.38 \mathrm{E}-04$ & $7.85 \mathrm{E}-04$ & $7.59 \mathrm{E}-04$ \\
\hline & & (9.0E-04) & (9.1E-04) & $(9.0 \mathrm{E}-04)$ \\
\hline & Constant & -0.205 & -0.187 & -0.222 \\
\hline & & $(0.065)$ & $(0.105)$ & $(0.093)$ \\
\hline & |Industrial Company & - & 0.006 & - \\
\hline.$\Xi$ & & - & $(0.084)$ & - \\
\hline పี & Bank & - & -0.040 & - \\
\hline कै & & - & $(0.159)$ & - \\
\hline 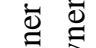 & Investment Fund & - & -0.053 & - \\
\hline है & & - & $(0.091)$ & - \\
\hline $4 \pi$ & Individual Owner & - & -0.048 & - \\
\hline 00 & & - & $(0.094)$ & - \\
\hline & Portfolio Company & - & -0.139 & - \\
\hline & & - & $(0.127)$ & - \\
\hline & |Industrial Company & - & - & 0.037 \\
\hline$\widehat{\Xi}$ & & - & - & $(0.068)$ \\
\hline$\Xi$ & Bank & - & - & -0.043 \\
\hline$\frac{3}{0}$ & & - & - & $(0.127)$ \\
\hline$\breve{\Xi}$ & Investment Fund & - & - & -0.036 \\
\hline & & - & - & $(0.074)$ \\
\hline 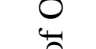 & Individual Owner & - & - & -0.002 \\
\hline 0 & & - & - & $(0.077)$ \\
\hline 光 & Portfolio Company & - & - & -0.051 \\
\hline & & - & - & $(0.098)$ \\
\hline & Industry dummies & Yes & Yes & Yes \\
\hline & Yearlv dummies & Yes & Yes & Yes \\
\hline & $\mathrm{R}^{2}$ & 0.041 & 0.042 & 0.041 \\
\hline
\end{tabular}


TABLE 14

Sales of Own Production

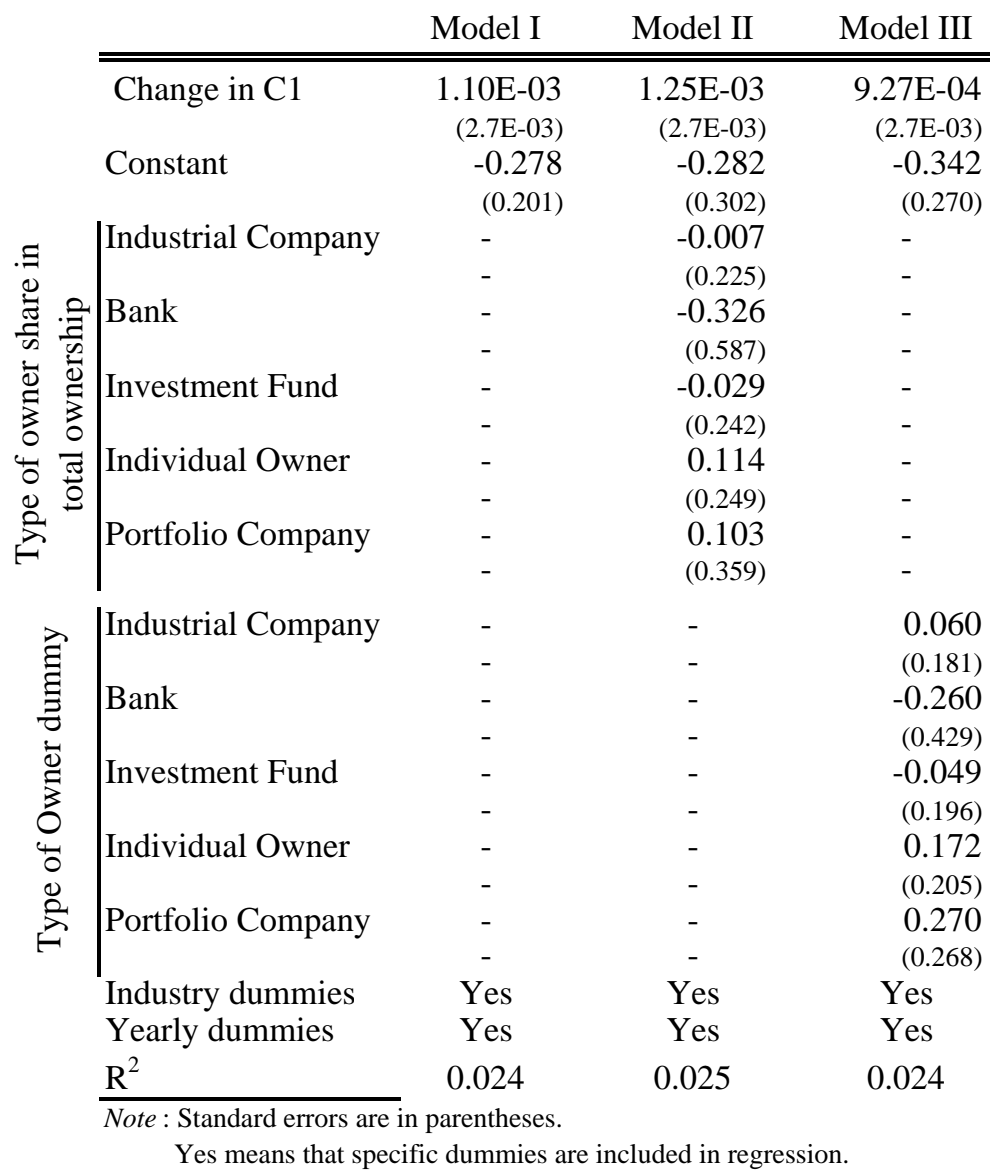


Figure 1

Density functions of concentration indexes for firms involved in voucher privatization
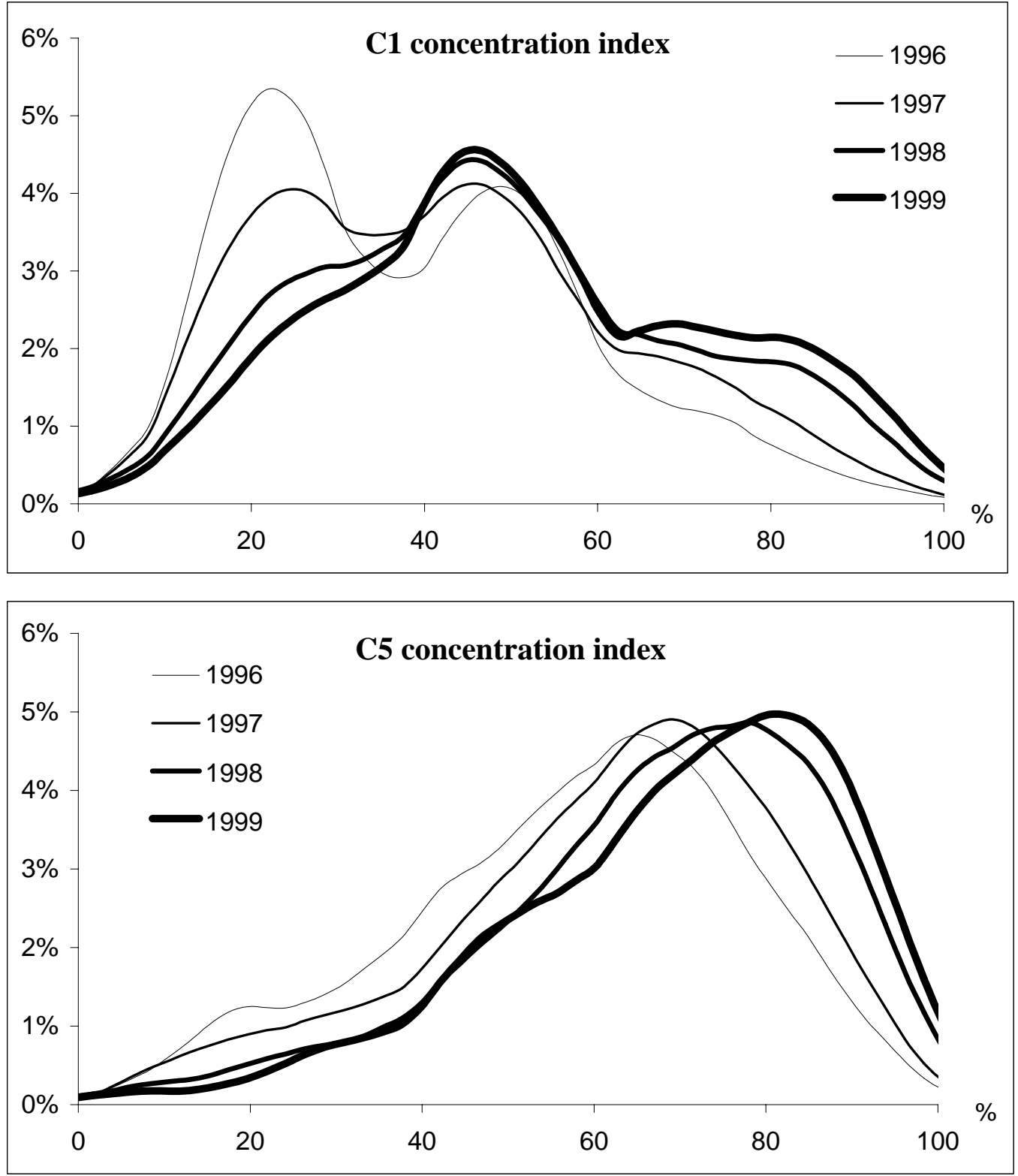

$\mathrm{C} 1$ represents the average percentage of the equity owned by the single largest investor and C5 that held by the five largest investors. 

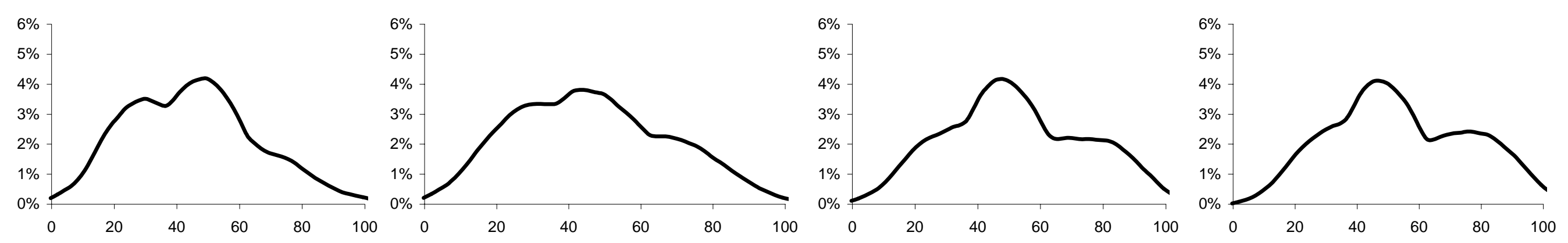

Bank
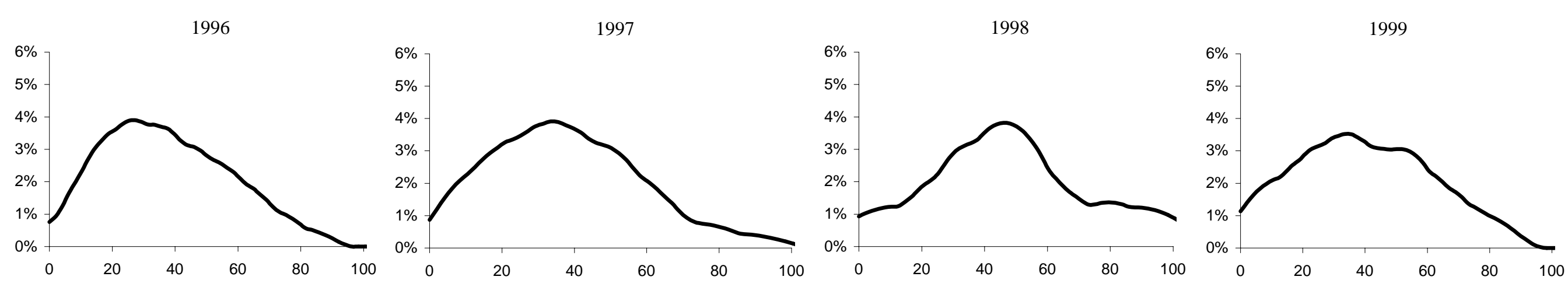

Investment Fund
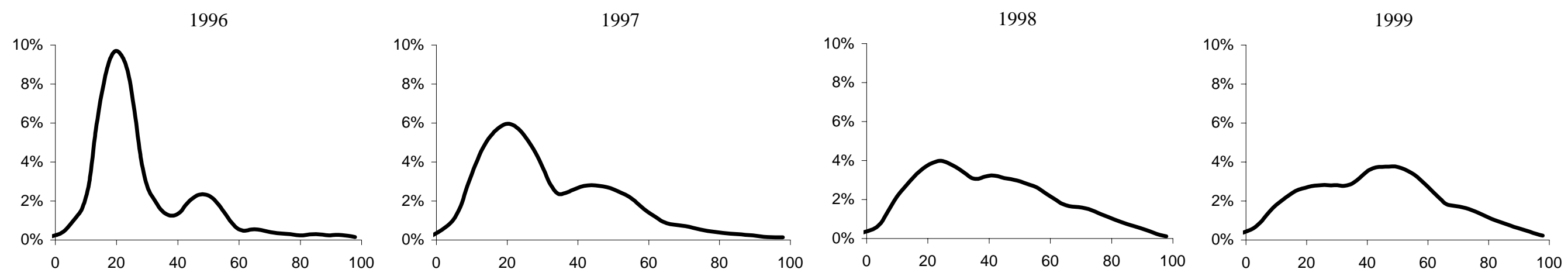
Individual Owner
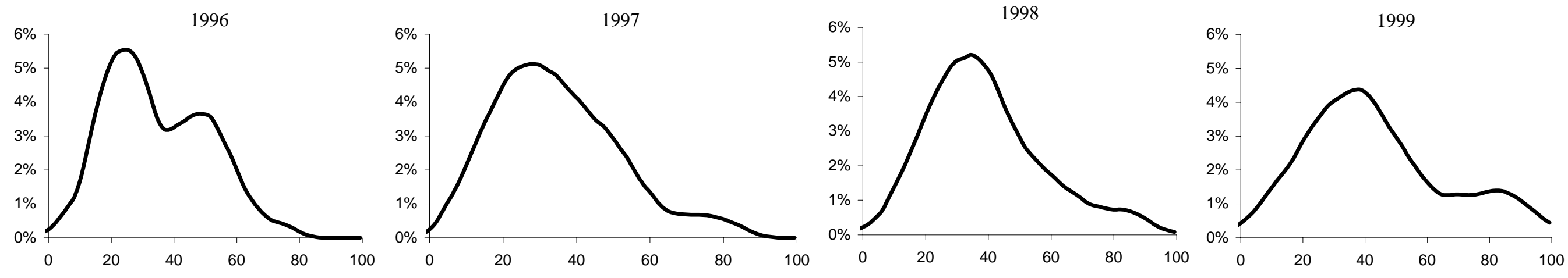

Portfolio Company
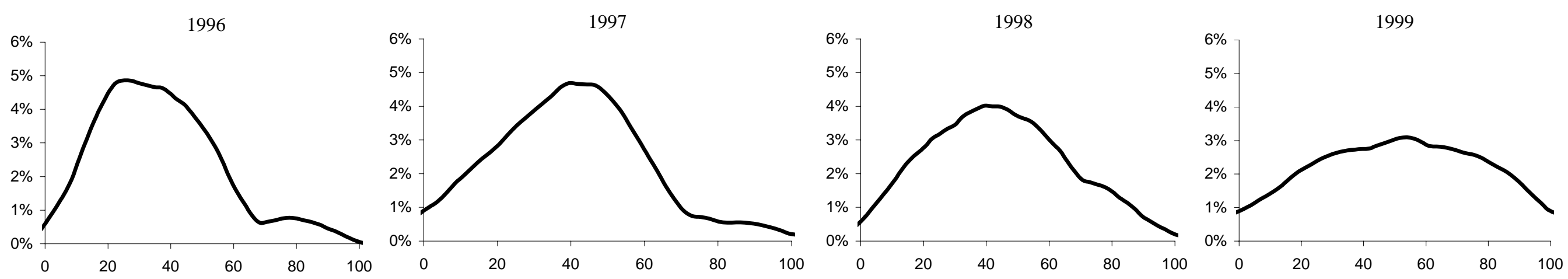

State
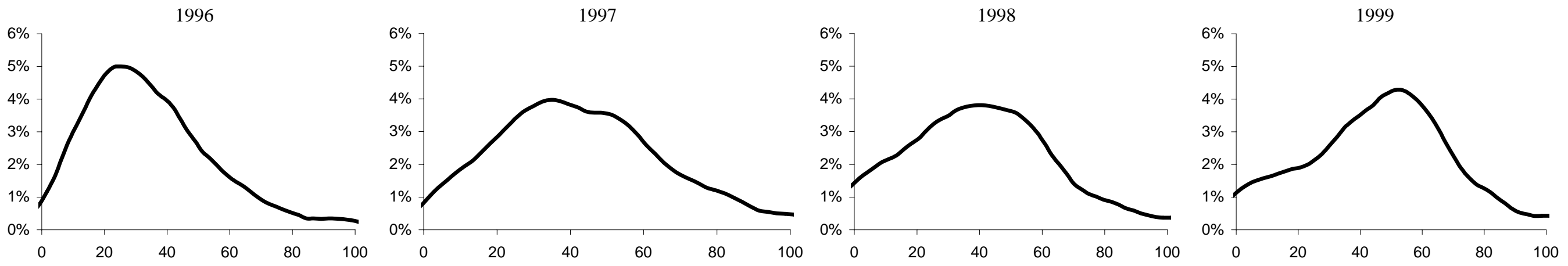